\title{
Recent advances in radiation therapy of pancreatic cancer
}

\section{[version 1; peer review: 2 approved]}

\section{Bhanu Prasad Venkatesulu1 ${ }^{1}$ Cheng-En Hsieh ${ }^{1-4}$, Keith L Sanders ${ }^{1}$, Sunil Krishnan (D1-3}

1Department of Experimental Radiation Oncology, University of Texas MD Anderson Cancer Center, Houston, TX, USA
2Department of Radiation Oncology, University of Texas MD Anderson Cancer Center, Houston, TX, USA
3The University of Texas MD Anderson Cancer Center-UT Health Graduate School of Biomedical Sciences, Houston, TX, USA
${ }^{4}$ Department of Radiation Oncology, Chang Gung Memorial Hospital, Linkou and Chang Gung University, Taoyuan, Taiwan

V1 First published: 13 Dec 2018, 7(F1000 Faculty Rev):1931

https://doi.org/10.12688/f1000research.16272.1

Latest published: 13 Dec 2018, 7(F1000 Faculty Rev):1931

https://doi.org/10.12688/f1000research.16272.1

\section{Abstract}

Pancreatic cancer has a dismal prognosis with an overall survival outcome of just $5 \%$ at five years. However, paralleling our improved understanding of the biology of pancreatic cancer, treatment paradigms have also continued to evolve with newer advances in surgical techniques, chemotherapeutic agents, radiation therapy (RT) techniques, and immunotherapy paradigms. RT dose, modality, fraction size, and sequencing are being evaluated actively, and the interplay between RT and immune effects has opened up newer avenues of research. In this review, we will emphasize recent advances in RT for pancreatic cancer, focusing on preoperative chemoradiation, RT dose escalation, sparing of the spleen to reduce lymphopenia, and combination of RT with immunotherapy.

\section{Keywords}

Dose escalation, immunotherapy, neoadjuvant therapy, spleen sparing, radiotherapy

\section{Open Peer Review}

Approval Status

1

2

version 1

13 Dec 2018

Faculty Reviews are review articles written by the prestigious Members of Faculty Opinions. The articles are commissioned and peer reviewed before publication to ensure that the final, published version is comprehensive and accessible. The reviewers who approved the final version are listed with their names and affiliations.

1. Terence Sio, Mayo Clinic, Phoenix, USA

2. Jeffrey Meyer, Johns Hopkins School of Medicine, Baltimore, USA

Any comments on the article can be found at the end of the article. 


\section{Corresponding author: Sunil Krishnan (SKrishnan@mdanderson.org)}

Author roles: Venkatesulu BP: Conceptualization, Investigation, Methodology, Writing - Original Draft Preparation, Writing - Review \& Editing; Hsieh CE: Investigation, Methodology, Writing - Original Draft Preparation, Writing - Review \& Editing; Sanders KL:

Investigation, Methodology, Writing - Review \& Editing; Krishnan S: Conceptualization, Investigation, Methodology, Supervision, Writing - Original Draft Preparation, Writing - Review \& Editing

Competing interests: No competing interests were disclosed.

Grant information: This study was supported in part by the MD Anderson Cancer Center support grant P30 CA16672 and funding from the John E. and Dorothy J. Harris Endowed Professorship and U01CA216468 (to SK).

The funders had no role in study design, data collection and analysis, decision to publish, or preparation of the manuscript.

Copyright: $\odot 2018$ Venkatesulu BP et al. This is an open access article distributed under the terms of the Creative Commons Attribution License, which permits unrestricted use, distribution, and reproduction in any medium, provided the original work is properly cited.

How to cite this article: Venkatesulu BP, Hsieh CE, Sanders KL and Krishnan S. Recent advances in radiation therapy of pancreatic cancer [version 1; peer review: 2 approved] F1000Research 2018, 7(F1000 Faculty Rev):1931

https://doi.org/10.12688/f1000research.16272.1

First published: 13 Dec 2018, 7(F1000 Faculty Rev):1931 https://doi.org/10.12688/f1000research.16272.1 


\section{Introduction}

Pancreatic cancer is the second most common gastrointestinal cancer in the United States, where there was an estimated incidence of 53,070 cases in 2016 ${ }^{1}$. Survival outcomes are dismal with a reported five-year overall survival (OS) rate of less than $5 \%^{2}$. Radiation therapy (RT) is an integral component of the arsenal against pancreatic cancer and is frequently used in the neoadjuvant, adjuvant, and palliative settings. In an everchanging landscape of treatment options for pancreatic cancer, some patterns are emerging that bear upon the utilization of RT in this disease. A recent autopsy study concluded thatindependent of initial clinical stage, histological features, and treatment course- $30 \%$ of patients die with locally destructive pancreatic cancer whereas $70 \%$ die with distant metastatic disease $^{3}$. Patients in this sizeable subset tend to lack inactivation of their DPC4 gene and may benefit considerably from intensified treatment with a local treatment modality. In agreement with this, post-pancreatectomy patterns-of-recurrence studies have shown that patients most commonly (about 50-60\%) recur systemically but that a large subset recur locally (20-25\%) or both locally and distantly (15-20\%). Again, local treatment modalities may play a significant role in minimizing local recurrence, and a greater understanding of biological predictors of varied patterns of recurrence should help elucidate potential ways to reduce the risk of recurrence ${ }^{4-6}$. Although these studies suggest that there is a role for local treatment intensification, there is little agreement on whether RT improves survival in patients by addressing this local recurrence risk, when this should be administered, how it is best administered, and what other principles dictate efficacy of treatment ${ }^{7-9}$. We address these gaps in knowledge in the next few sections and highlight advances in our understanding of the role of radiotherapy in pancreatic cancer.

\section{Defining a borderline resectable pancreatic cancer subset}

Historically, localized non-metastatic pancreatic cancers were categorized as locally advanced or resectable on the basis of the likelihood of major vascular involvement on radiographic studies that dictated whether or not a margin-negative $\mathrm{R} 0$ resection was feasible. Radiographic assessment sheds light on involvement of the retroperitoneal margin-superior mesenteric artery (SMA) and superior mesenteric vein (SMV) - as well as that of the celiac artery and confluence of the SMV and the portal vein $(\mathrm{PV})$. More recently, a new category of borderline resectable pancreatic cancer (BRPC) has been created wherein there is some degree of involvement of vascular structures that could compromise achievement of an R0 resection. A number of groups have tried to define criteria for resectability ${ }^{10,11}$. The consensus includes anatomic criteria such as feasibility of reconstruction of SMV-PV confluence, less than $180^{\circ}$ involvement of the SMA and celiac axis, and common hepatic artery origin from celiac axis that can be reconstructed. Some groups also include in this category patients with uncertainty regarding metastatic stage usually arising from indeterminate distant lesions on radiographic studies and poor performance status that would preclude immediate surgery ${ }^{11}$.

The creation of a category of BRPC dovetails with the recognition that the technically challenging nature of resection along the retroperitoneal margin results in patients frequently undergoing an incomplete (margin-positive) resection ${ }^{12-18}$. In many studies, resection margin status - in addition to tumor size, stage, and grade-is considered an important predictor of early recurrence and inferior survival rates ${ }^{15,16,18-22}$. This poor survival rate re, $23,24^{24}$ closely mimics that of patients with locally advanced pancreatic cancer $(\mathrm{LAPC})^{25}$. Furthermore, postoperative chemoradiation therapy (CRT) does not overcome the unfavorable prognosis conferred by a margin-positive resection ${ }^{12,14}$. Therefore, leaving behind a positive margin at surgery is essentially akin to not having undergone surgery at all since the survival outcomes are no better than those of LAPC patients who did not undergo surgical resection in the first place ${ }^{12,14,20,23-25}$. Notably, during the recovery time from this surgery, patients are unable to receive chemotherapy or RT, further hampering early and effective disease control locally and distantly. Recognizing the detrimental effect of margin-positive resections and creating a BRPC category allow better selection of patients for surgical resection. Importantly, they also offer the opportunity to deliver some neoadjuvant therapy to patients with BRPC to make them potentially resectable and to reduce the likelihood that this resection will be a margin-positive $\mathrm{R} 1$ resection.

\section{Preoperative chemoradiation}

Preoperative therapy has been explored by a number of groups in both potentially resectable pancreatic cancer and BRPC. While the optimal treatment approaches for all categories of non-metastatic pancreatic cancer remain controversial, for BRPC, the most compelling argument for neoadjuvant therapy is to convert them to potentially resectable tumors by sterilizing the retroperitoneal margin. For potentially resectable pancreatic cancers, a number of arguments can be made for neoadjuvant therapy. In pancreatic cancers, as in other cancers where preoperative therapy is used routinely (rectal and esophageal) ${ }^{26,27}$, preoperative treatment allows (a) better tissue penetration of drug and oxygen, resulting in greater response to chemotherapy and radiotherapy, respectively; (b) greater chances of an R0 resection (since even potentially resectable pancreatic cancers that go to surgery upfront often encounter positive margins and perineural invasion); (c) better outcomes even if the resection ends up being $\mathrm{R} 1^{28}$; (d) lower risk of anastomotic leaks at the pancreaticojejunostomy site because of firmer post-radiation pancreatic tissue that sutures go through ${ }^{29-31}$; and (e) the ability to select patients who pass the stress test of neoadjuvant treatment satisfactorily and do not develop interval metastases or newly diagnosed, previously occult metastatic disease (both good performance status and true non-metastatic localized disease serving as clinical indicators of a favorable biology). By relegating the most challenging treatment (that is, surgery) to the end of the treatment course, this approach also ensures a high probability of patients receiving all three components of treatment (surgery, chemotherapy, and radiotherapy) rather than suffer from delays in or abandonment of treatment (20-30\% of patients are unable to receive planned postoperative therapy) because of prolonged recovery times from surgery or new metastatic disease manifesting itself during the recovery periods ${ }^{32}$.

A number of phase II studies have evaluated the role of CRT in the neoadjuvant setting for potentially resectable pancreatic cancer. A meta-analysis ${ }^{33}$ noted that neoadjuvant therapy for 
initially resectable tumors resulted in a $4 \%$ complete radiographic or pathologic response rate, $31 \%$ partial radiographic or pathologic response rate, $74 \%$ resectability, and a median OS of 23.3 months, which is similar to that of patients who undergo surgery upfront. In the first prospective randomized phase II trial, the German investigators compared surgery followed by six cycles of gemcitabine to neoadjuvant gemcitabine, cisplatin, and RT (50.4 Gy to the regional nodes and 55.8 Gy to the tumor) followed by surgery and six cycles of adjuvant gemcitabine chemotherapy. The study was terminated early after enrollment of only a quarter of planned patients because of slow accrual but noted a median OS of 17.4 months with neoadjuvant CRT compared with 14.4 months with adjuvant chemotherapy arm $(P=0.96)$ with comparable R0 and pN0 resections in both $\operatorname{arms}^{34}$. When patients with BRPC are also included, the potential benefit of neoadjuvant therapy seems to be more apparent, as was hinted at in the meta-analysis above. The meta-analysis noted that, for initially unresectable BRPC and LAPC, neoadjuvant therapy resulted in 5\% radiographic or pathologic complete response rate, $30 \%$ partial response rate, $33 \%$ resectability, and a median OS of 20.5 months, which is comparable to that of initially resectable patients.

Early results of the multi-center randomized phase III PREOPANC-1 study presented recently at the American Society of Clinical Oncology 2018 annual meeting compared preoperative CRT with adjuvant chemotherapy in 246 patients, split nearly evenly between BRPC and potentially resectable patients ${ }^{35}$. The preoperative therapy arm received a cycle of gemcitabine followed by gemcitabine and RT (36 Gy in 15 fractions) and another cycle of gemcitabine before surgery and four cycles of postoperative gemcitabine, whereas the adjuvant chemotherapy arm received six cycles of gemcitabine. Preoperative treatment resulted in improved median OS (17.1 versus 13.5 months, $P=0.74)$ and greater time to recurrence $(9.9$ versus 7.9 months, $P=0.023)$ and R0 resection rate $(63 \%$ versus $31 \%, P<0.001)$ without any difference in toxicity profiles. Notably, among patients who underwent surgery, the median OS was significantly better in the neoadjuvant arm than in the adjuvant arm (29.9 versus 16.8 months, $P<0.001)$. Although these results are promising and suggest that patients with BRPC should receive neoadjuvant therapy followed by re-evaluation for resectability, the ideal approach would be to treat patients on protocols to establish the value of neoadjuvant therapy more objectively. One such study that is accruing currently is the randomized phase II Alliance for Clinical Oncology trial (A021501) where patients with BRPC receive FOLFIRINOX (oxaliplatin, irinotecan, leucovorin, and infusional 5-fluorouracil) alone or FOLFIRINOX followed by stereotactic body RT (SBRT) of $33-40$ Gy in five fractions before surgery ${ }^{36}$.

\section{Radiation dose escalation in pancreatic cancer}

Radiation dose escalation has been studied the most in LAPC where treatment outcomes are poorer than for resectable and borderline resectable patients and the likelihood of conversion to resectability is low. The randomized phase III LAP-07 trial showed that CRT of 54 Gy with gemcitabine after 4 months of gemcitabine-based chemotherapy did not provide an OS benefit compared with 6 months of chemotherapy alone in LAPC but CRT was associated with reduced local progression $(32 \%$ versus $46 \%, P=0.03)$. The findings of this study suggest that standard-dose RT produces good local control but treatment intensification may be warranted to improve $\mathrm{OS}^{37}$. Treatment intensification could be achieved via more potent chemotherapy such as FOLFIRINOX or gemcitabine-Nab-paclitaxel or via radiation dose escalation. As systemic therapy becomes more effective, the local failure may become a cause for greater concern if it exceeds the nearly $30 \%$ of patients who were noted to die with locally destructive pancreatic cancer in the autopsy series described previously.

A viable option for improving local control is to escalate the dose of RT to the tumor while respecting normal tissue dose constraints. This can be accomplished via standard courses of fractionated RT of about five weeks with incremental increases in dose-per-fraction to the planning target volume with the option of an integrated boost to the gross tumor volume typically achieved with intensity-modulated RT (IMRT) or via SBRT, where higher doses of radiation are administered to small tumor volumes with precise image guidance and motion management. Figure 1 highlights a patient who had dose escalation of 70 Gy to the gross tumor volume through IMRT. In both instances, the close proximity of gastrointestinal mucosa (stomach, duodenum, and jejunum) precluded excessive dose escalation. In a phase III randomized French study, gemcitabine alone was compared with 5-fluorouracil, cisplatin, and $60 \mathrm{~Gy}$ of RT to a large pancreatic field followed by gemcitabine ${ }^{38}$. The chemotherapy-alone arm fared better with a median OS of 13 months compared with 8.6 months $(P=0.03)$ but was also significantly less toxic. The unusually low OS on the CRT arm indicated that radiation dose escalation is potentially deleterious if performed without image guidance and if combined with overly intensive chemotherapy. On the other hand, Chung et al. reported that dose escalation of more than 61 Gy leads to better one-year OS and progression-free survival (PFS) ${ }^{39}$. Krishnan et al. reported that patients who received a biologically equivalent dose (BED) greater than 70 Gy had superior OS (17.8 versus 15 months, $P=0.03)$ as well as better local PFS (10.2 versus 6.2 months, $P=0.05)$ compared with those receiving BED of less than 70 $\mathrm{Gy}^{40}$. It is noteworthy that this trial reported outcomes from the start of RT and not from the date of diagnosis and yet the high BED cohort had a remarkable three-year OS of $31 \%$. Admittedly, this was possible in only a subset of patients whose tumors were at least $1 \mathrm{~cm}$ away from bowel mucosa and required daily image guidance, motion tracking and control, and maintenance of an empty stomach for 3 hours before treatment in the majority of patients. Most patients did not require fiducial placement since daily volumetric imaging was available on a CT-on-rails. With similar attention to organ motion and image guidance, the other approach that is convenient and easily incorporated into the overall management plan of patients is SBRT in which a high BED can be administered in a short duration. Again, respecting bowel mucosal constraints is critical since this is an organ with serial functional subunits (like the spinal cord) and excessive dose to even a small volume could result in significant functional compromise and toxicity. With gentler fractionation of five fractions, a moderate dose of 33 Gy has now been safely administered to a large number of patients. A multi-institutional phase II study demonstrated that gemcitabine with SBRT of 33 Gy in five fractions over the course of one week is safe and technically 

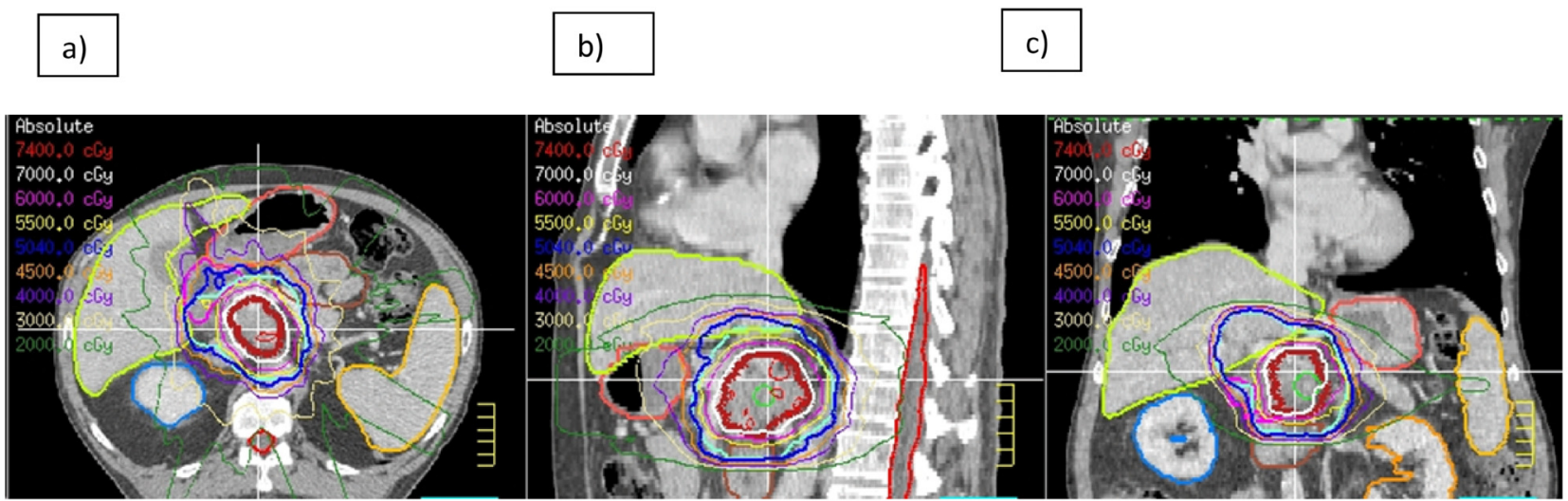

\section{d)}

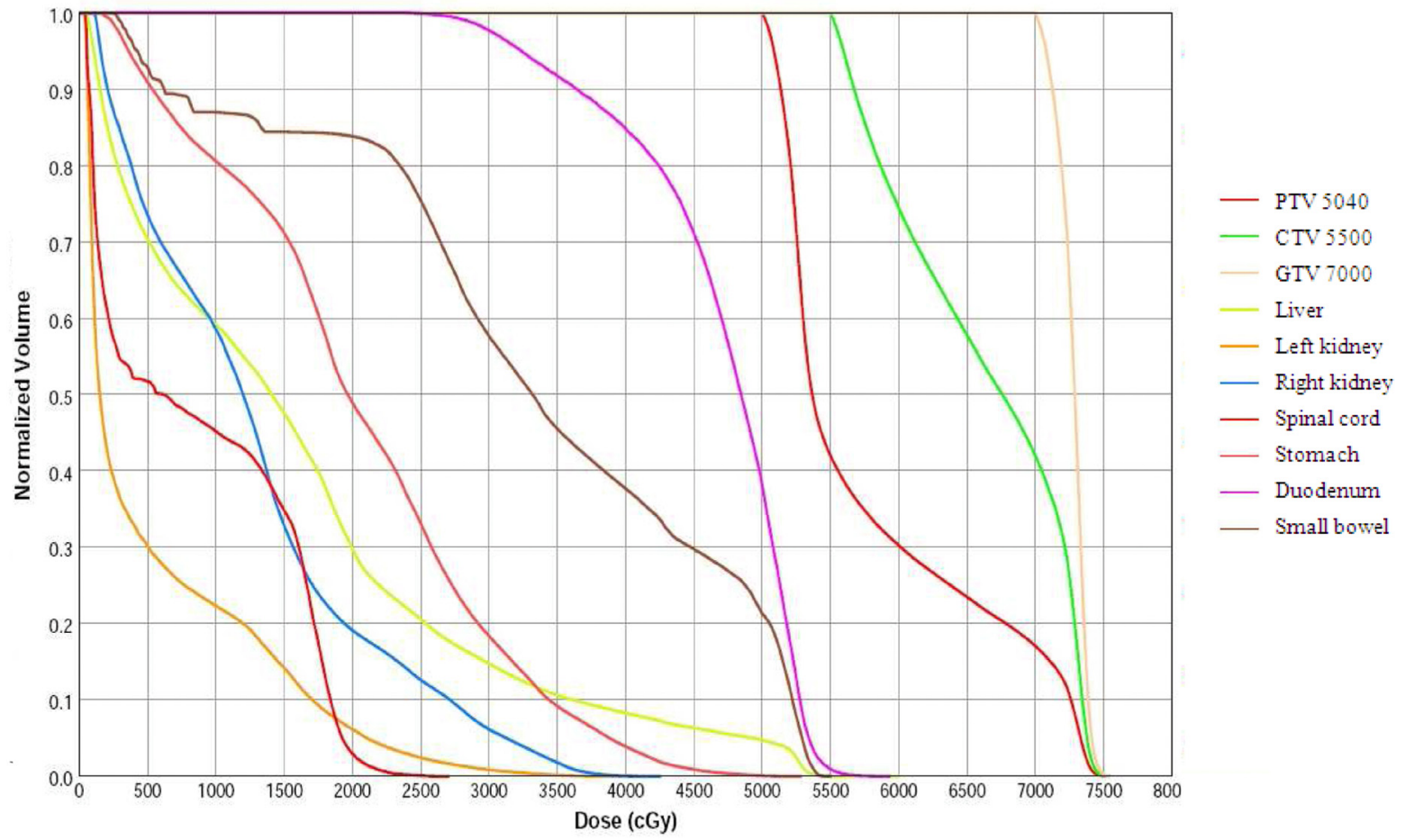

Figure 1. Representative images and treatment plan for dose-escalated radiation therapy for pancreatic cancer. Axial (a), sagittal (b), and coronal (c) view of a patient who received 50.4 Gy in 28 fractions to the planning target volume with simultaneous integrated boost of 55 Gy to the clinical target volume and 70 Gy boost to the gross tumor volume. (d) Dose volume histogram of the targets and organs at risk. This figure was produced by SK, (a), (b) and (c) uses original images taken in SK's clinic for this publication.

feasible in $\mathrm{LAPC}^{41}$. As noted above, the Alliance for Clinical Oncology Trial A021501 seeks to gently increase the radiation dose up to 40 Gy in five fractions in patients with BRPC, bringing it closer to ablative doses of radiation used in the treatment of liver tumors ${ }^{36}$. By intensifying the systemic therapy as well as the local therapy, this trial will address both causes of failure in patients.

An alluring option that is worth considering is that of being less stringent with defining who proceeds to surgery after neoadjuvant CRT. For instance, among the first large reports of BRPC treatment with preoperative CRT, only $41 \%$ of 160 patients who completed preoperative therapy and restaging advanced to pancreatectomy, $94 \%$ of which were margin-negative pancreatectomies $^{42}$. One could argue that the very low rates of margin positivity suggest that resectability criteria are too stringent. More recently, it was noted that neoadjuvant FOLFIRINOX did not convert locally advanced and borderline resectable patients to resectable by radiographic criteria in a majority of patients; even so, when taken to surgery, the R0 resection rate was $92 \%{ }^{43}$. This suggests that traditional radiological criteria for resectability may overestimate the likelihood 
of margin positivity and that adoption of less stringent criteria may increase the number of patients going to surgery without a large increase in margin positivity. Extended to its logical conclusion, this conjecture would result in a three-pronged fork in the road after completion of CRT. The first prong (say, the good) would be those patients with clear traditional radiological criteria for resectability who would go to surgery. The second (say, the bad) would be those patients with traditional radiological criteria that would not warrant surgery but there are no adverse factors such as worsening performance status, questionable new metastases, unexplained tumor marker increase, or complete encasement of celiac axis or SMA. They merely have involvement of the SMA or celiac axis that precludes resectability by traditional radiological criteria. These patients would undergo reimaging in a couple of months and, if all criteria remain unchanged, would undergo surgery with an implicit acceptance of a higher likelihood of $\mathrm{R} 1$ resections. The third (say, the ugly) would be patients with encasement of vessels, worsening performance status, questionable new metastases, and rising tumor markers. These patients would not go to surgery. While treatment paradigms are slowly shifting in this direction for BRPC, such a trend is lacking in LAPC. Treatment of patients on protocols may help define the value of such an approach more objectively.

\section{Spleen as a dose-limiting organ in pancreatic cancer radiotherapy}

A preponderance of evidence suggests that lymphopenia, especially that following RT, confers a poor prognosis in the treatment of a variety of cancers ${ }^{44}$. This was also observed in pancreatic cancer in a study from Johns Hopkins University where posttreatment lymphopenia correlated with increased mortality in resectable pancreatic cancer and LAPC. RT toxicity to circulating lymphocytes was postulated as the likely cause of lymphopenia that was independent of chemotherapy usage. Mortality was reported to be due to tumor progression rather than lymphopenia-related opportunistic infections ${ }^{45,46}$. A report from the MD Anderson Cancer Center also demonstrated that post-CRT lymphopenia occurred in roughly a third of all patients with LAPC and was strongly associated with poor survival outcomes. Importantly, however, the dose to the spleen (mean dose exceeding 9 Gy and V15 exceeding 20\%) was an independent predictor of post-CRT lymphopenia, suggesting that the detrimental effect of lymphopenia is potentially minimized by sparing the spleen $^{47}$. The spleen routinely receives unintentional radiation dose while irradiating pancreatic cancers not only because it lies in close proximity to the pancreas but also because it is not commonly viewed as a dose-limiting organ while developing treatment plans. However, it is a rich reservoir of $\mathrm{T}$ and $\mathrm{B}$ lymphocytes that slowly traverse through the sinusoidal architecture of flow channels within it, allowing ample time for collateral radiation injury during each fraction of treatment. Conceivably, this depletion of resident or slow-moving lymphocytes in the spleen could also reduce the levels of $\mathrm{CD} 8^{+}$cytotoxic $\mathrm{T}$ lymphocytes and $\mathrm{CD}^{+}{ }^{+}$helper $\mathrm{T}$ cells available for tumor infiltration. In turn, this could adversely impact OS outcomes as noted in surgical series where less tumor infiltration with $\mathrm{CD}^{+} \mathrm{T}$ cells is associated with poorer $\mathrm{OS}^{48,49}$ and reduce the effectiveness of future potential immunotherapies that rely on the presence of a pool of healthy lymphocytes for activation and tumor homing ${ }^{50}$. Of note, tumor size, field size, irradiated volume (encompassed by the $50 \%$ isodose line), and treated volume (encompassed by the $95 \%$ isodose line) did not independently predict the likelihood of developing lymphopenia, suggesting that depletion of circulating lymphocytes may not be a dominant mechanism of developing lymphopenia in patients with pancreatic cancer.

The correlation between splenic dose and lymphopenia needs to be independently validated in other series. However, since it is unlikely that prospective studies will establish the clinical benefit of spleen-sparing RT for pancreatic cancer, treatment plans could be readily triaged on the basis of their ability to adequately spare the spleen. In patients most vulnerable to developing lymphopenia or having poor outcomes from lymphopenia such as patients with baseline lymphopenia prior to initiating CRT, patients who are candidates for immunotherapy, and patients being considered for RT dose escalation protocols, one could consider using spleen-sparing beam angles for three-dimensional conformal RT, IMRT, increased dose rates for beam delivery, charged particle therapy, and SBRT ${ }^{51,52}$. More refined normal tissue complication probability modeling may also serve as a predictive tool to spatially correlate splenic dose volume histograms with lymphopenia.

Alternatively, strategies could be developed to replenish or protect lymphocytes (or both) from damage mediated by RT. Preclinical models have demonstrated that interleukin-7 (IL-7) and IL-15 administration to irradiated mice resulted in greater tumor regression which was associated with an increase in $\mathrm{CD}^{+}$ cytotoxic $\mathrm{T}$ cell counts without an increase in immunosuppressive regulatory $\mathrm{T}$ cell counts $\mathrm{s}^{53-55}$. A phase I clinical trial is exploring IL-7 administration in high-grade glioma patients who develop lymphopenia after completion of CRT ${ }^{56}$. IL-15 is being evaluated as monotherapy in metastatic melanoma and renal cell carcinoma, albeit not for lymphopenia ${ }^{57}$. It would be worthwhile to evaluate the role of IL-15 as a rescue agent for lymphopenia following RT. Lymphocyte reconstitution is frequently used as a rescue strategy following myeloablative chemotherapy and RT in transplant protocols and adoptive T-cell therapy ${ }^{58}$. In one study, autologous lymphocytes harvested before temozolomide-RT for high-grade gliomas were reinfused after completion of treatment. However, the return of lymphocyte counts following radiation-induced depletion was no different between reinfused patients and matched controls ${ }^{59}$.

\section{Immunotherapy with radiation in pancreatic cancer}

Consistent with the notion that lymphocytes play a crucial role in determining treatment outcomes of these patients, pancreatic cancer has also been the focus of immuno-oncology studies aimed at arousing the immune system to combat cancer progression and metastasis. However, pancreatic cancer poses a unique challenge to immunotherapy because of the presence of a thick fibrous capsule with intense desmoplastic stroma that counteracts the entry of immune cells. In addition, the pancreatic tumor milieu has a preponderance of regulatory $\mathrm{T}$ cells, myeloid-derived suppressor cells, and M2 macrophages that contribute to the immunosuppressive tumor microenvironment ${ }^{60}$. Pancreatic cancer tends to produce IL-10, transforming growth factor-beta (TGF$\beta$ ), and increased expression of programmed death-ligand 1 (PD-L1) that prevents activation of tumor antigen-specific T cells. 
Nevertheless, accumulating evidence of a synergy between immunotherapy and radiotherapy has resulted in enormous growth of this area as a promising and exciting avenue of research. Herein, RT is seen as serving as an in situ vaccine via release of autoantigens and radiation-induced neoantigens that are displayed to antigen-presenting cells that then cross-present tumor antigen to prime $\mathrm{T}$ cells to mount a cytotoxic tumor-specific immune response. RT triggers the elaboration of a damage-associated molecular pattern (DAMP) response wherein cells display hallmarks of the "eat me" phenotype that leads to phagocytosis by antigen-presenting cells. In turn, these antigen presenting cells cross-present tumor antigens to $\mathrm{T}$ cells which enable immune-mediated tumor killing ${ }^{61}$. But RT can also be immunosuppressive by upregulating the expression of death receptors and immune checkpoint proteins that drive co-inhibitory pathways to evade immune eradication. Also, RT can induce lymphocyte apoptosis via secretion of galectin-1 by tumors and lead to secretion of TGF- $\beta$ into the tumor microenvironment, thereby hindering the ability to mount an effective cytotoxic T-cell response to tumor antigens ${ }^{62-64}$. Careful tuning of this balance between immunostimulatory and immunosuppressive effects of radiation can lead to a dominance of immune stimulation and immune-mediated tumor eradication. Preclinical studies suggest that an ablative dose of RT has the potential for potent T-cell priming in draining lymph nodes, facilitation of increased antigen presentation, activation of immune response-related genes, radiation-induced DAMP molecules, and increased release of inflammatory cytokines.

SBRT may have a unique role in synergizing with immunotherapy because the high dose induces a dominant in situ vaccination effect and the small number of fractions leads to less depletion of primed and activated cytotoxic $\mathrm{T}$ cells returning to the tumor ${ }^{65}$. Currently, over 30 clinical trials are evaluating immunotherapy in pancreatic cancer. Algenpantucel-L is an alpha-1, 3-galactosyl transferase-expressing allogeneic pancreatic tumor cell vaccine that is supposed to cause rapid activation of antibody-dependent cell-mediated cytotoxicity (toward pancreatic cancer cells). GVAX is a cancer vaccine that has been genetically modified to produce granulocyte-macrophage colony-stimulating factor (GM-CSF) that induces a robust T-cell response. Both of these agents are being evaluated with SBRT $^{66,67}$. Losartan, via inhibition of the renin-angiotensin system, downregulates TGF- $\beta$ activity, thereby facilitating intratumoral penetration of drugs by stromal and vascular remodeling. Studies are evaluating the combination of losartan and PD-L1 blockade with SBRT. Other studies are exploring the combination of immune checkpoint inhibitors-antibodies to cytotoxic $\mathrm{T}$ lymphocyte-associated protein 4 (CTLA-4) and PD-L1with SBRT and chemotherapy to find the optimal combination that generates durable treatment responses and improved $\mathrm{OS}^{68-71}$. Although immunotherapy holds promise in pancreatic cancer, pragmatic clinical trials with optimal sequencing of immunotherapy and RT are needed ${ }^{72}$. Finding innovative ways to enhance the permeability of the pancreatic cancer stromal matrix for efficient drug delivery may hold the key to enhancing the effect of immunotherapy, especially because metastases are as stroma-rich as the primary tumor $^{73}$; radiation may play a role in magnifying the role of immunotherapeutic agents through judicious elaboration of its in situ vaccine effect. Table 1 summarizes the currently active clinical trials that combine radiotherapy with immunotherapy in pancreatic cancer.

Table 1. Summary of the currently active clinical trials that are ongoing that combine radiation with immunotherapy in pancreatic cancer.

\begin{tabular}{|c|c|c|c|c|c|}
\hline $\begin{array}{l}\text { ClinicalTrials.gov } \\
\text { Identifier }\end{array}$ & Phase & Title & Intervention & $\begin{array}{l}\text { Radiation } \\
\text { detail }\end{array}$ & Disease stage \\
\hline NCT02648282 & 2 & $\begin{array}{l}\text { Study With CY, Pembrolizumab, } \\
\text { GVAX, and SBRT in Patients With } \\
\text { Locally Advanced Pancreatic } \\
\text { Cancer }\end{array}$ & $\begin{array}{l}\text { Cyclophosphamide } \\
\text { GVAX } \\
\text { Pembrolizumab }\end{array}$ & $\begin{array}{l}6.6 \text { Gy per day } \\
\text { over the course } \\
\text { of } 5 \text { days }\end{array}$ & $\begin{array}{l}\text { Locally advanced pancreatic } \\
\text { cancer }\end{array}$ \\
\hline NCT03104439 & 2 & $\begin{array}{l}\text { Nivolumab and Ipilimumab } \\
\text { and Radiation Therapy in MSS } \\
\text { and MSI High Colorectal and } \\
\text { Pancreatic Cancer }\end{array}$ & $\begin{array}{l}\text { Nivolumab } \\
\text { Ipilimumab }\end{array}$ & $\begin{array}{l}8 \text { Gy per day } \\
\text { over the course } \\
\text { of } 3 \text { days }\end{array}$ & $\begin{array}{l}\text { Oligometastatic pancreatic } \\
\text { cancer }\end{array}$ \\
\hline NCT03161379 & 2 & $\begin{array}{l}\text { Phase } 2 \text { GVAX Pancreas Vaccine } \\
\text { (With CY) in Combination With } \\
\text { Nivolumab and SBRT for Patients } \\
\text { With Borderline Resectable } \\
\text { Pancreatic Cancer }\end{array}$ & $\begin{array}{l}\text { Cyclophosphamide } \\
\text { Nivolumab } \\
\text { GVAX }\end{array}$ & $\begin{array}{l}6.6 \text { Gy per day } \\
\text { over the course } \\
\text { of } 5 \text { days }\end{array}$ & $\begin{array}{l}\text { Borderline Resectable } \\
\text { Pancreatic Adenocarcinoma }\end{array}$ \\
\hline NCT02305186 & $1 / 2$ & $\begin{array}{l}\text { Safety and Immunological Effect } \\
\text { of Pembrolizumab in Resectable } \\
\text { or Borderline Resectable } \\
\text { Pancreatic Cancer (UVA-PC- } \\
\text { PD101) }\end{array}$ & $\begin{array}{l}\text { Pembrolizumab } \\
\text { Capecitabine }\end{array}$ & $\begin{array}{l}50.4 \text { Gy in } 28 \\
\text { fractions over } \\
\text { the course of } 28 \\
\text { days }\end{array}$ & $\begin{array}{l}\text { Resectable or Borderline } \\
\text { Resectable Pancreatic } \\
\text { Cancer }\end{array}$ \\
\hline NCT03563248 & 2 & $\begin{array}{l}\text { Losartan and Nivolumab in } \\
\text { Combination With FOLFIRINOX } \\
\text { and SBRT in Localized } \\
\text { Pancreatic Cancer }\end{array}$ & $\begin{array}{l}\text { 5-Fluorouracil Oxaliplatin } \\
\text { Irinotecan } \\
\text { Leucovorin } \\
\text { Losartan } \\
\text { Nivolumab }\end{array}$ & SBRT & $\begin{array}{l}\text { Borderline/potentially } \\
\text { resectable or locally } \\
\text { advanced. }\end{array}$ \\
\hline
\end{tabular}

CY, cyclophosphamide; GVAX, granulocyte-macrophage colony-stimulating factor (GM-CSF) gene-transfected tumor cell vaccine; MSI, microsatellite instable; MSS, microsatellite stable; SBRT, stereotactic body radiotherapy. 


\section{Conclusions}

Exciting new clinical research suggests that the outcomes in pancreatic cancer can be improved by a multi-pronged approach. Careful stratification of patients into distinct categories, adoption of neoadjuvant therapy for resectable and borderline resectable categories, judicious focal dose escalation with image guidance and motion management, avoidance of splenic irradiation to reduce lymphopenia, and potentially the combination of RT with immunotherapeutic agents may all have a role in the optimal management of pancreatic cancer with RT in the future. For now, these approaches address critical challenges faced while considering RT during the treatment of pancreatic cancer and only continued evaluation of such strategies on clinical trials will address persisting gaps in knowledge.

\section{Grant information}

This study was supported in part by the MD Anderson Cancer Center support grant P30 CA16672 and funding from the John E. and Dorothy J. Harris Endowed Professorship and U01CA216468 (to SK).

The funders had no role in study design, data collection and analysis, decision to publish, or preparation of the manuscript.
1. $\quad F$ Siegel RL, Miller KD, Jemal A: Cancer statistics, 2016. CA Cancer J Clin 2016; 66(1): 7-30.

PubMed Abstract | Publisher Full Text | F1000 Recommendation

2. Hidalgo M: Pancreatic cancer. N Engl J Med. 2010; 362(17): 1605-17. PubMed Abstract | Publisher Full Text

3. lacobuzio-Donahue CA, Fu B, Yachida S, et al.: DPC4 gene status of the primary carcinoma correlates with patterns of failure in patients with pancreatic cancer. J Clin Oncol. 2009; 27(11): 1806-13.

PubMed Abstract | Publisher Full Text | Free Full Text

4. Sperti C, Pasquali C, Piccoli A, et al:: Recurrence after resection for ductal adenocarcinoma of the pancreas. World J Surg. 1997; 21(2): 195-200. PubMed Abstract | Publisher Full Text

5. Van den Broeck A, Sergeant G, Ectors N, et al.: Patterns of recurrence after curative resection of pancreatic ductal adenocarcinoma. Eur J Surg Oncol. 2009; 35(6): 600-4.

PubMed Abstract | Publisher Full Text

6. F Groot VP, Rezaee N, Wu W, et al: Patterns, Timing, and Predictors of Recurrence Following Pancreatectomy for Pancreatic Ductal Adenocarcinoma. Ann Surg. 2018; 267(5): 936-45.

PubMed Abstract | Publisher Full Text | F1000 Recommendation

7. Chadha AS, Khoo A, Aliru ML, et al:: Recent Advances and Prospects for Multimodality Therapy in Pancreatic Cancer. Semin Radiat Oncol. 2016; 26(4): $320-37$.

PubMed Abstract | Publisher Full Tex

8. Krishnan S, Ahmad M: Intensifying local radiotherapy for pancreatic cancerwho benefits and how do we select them? J Gastrointest Oncol. 2013; 4(4): 337-9.

PubMed Abstract | Publisher Full Text | Free Full Text

9. Krishnan S, Rana V, Janjan NA, et al:: Induction chemotherapy selects patients with locally advanced, unresectable pancreatic cancer for optimal benefit from consolidative chemoradiation therapy. Cancer. 2007; 110(1): 47-55. PubMed Abstract | Publisher Full Text

10. Callery MP, Chang KJ, Fishman EK, et al.: Pretreatment assessment of resectable and borderline resectable pancreatic cancer: expert consensus statement. Ann Surg Oncol. 2009; 16(7): 1727-33.

PubMed Abstract | Publisher Full Text

11. Varadhachary GR, Tamm EP, Abbruzzese JL, et al:: Borderline resectable pancreatic cancer: definitions, management, and role of preoperative therapy. Ann Surg Oncol. 2006; 13(8): 1035-46. PubMed Abstract | Publisher Full Text

12. Willett $\mathrm{CG}$, Lewandrowski $\mathrm{K}$, Warshaw $\mathrm{AL}$, et al:: Resection margins in carcinoma of the head of the pancreas. Implications for radiation therapy. Ann Surg. 1993; 217(2): 144-8.

PubMed Abstract | Publisher Full Text | Free Full Text

13. Yeo CJ, Cameron JL, Lillemoe KD, et al.: Pancreaticoduodenectomy for cancer of the head of the pancreas. 201 patients. Ann Surg. 1995; 221(6): 721-31; discussion 731-3.

PubMed Abstract | Publisher Full Text | Free Full Text

14. Nitecki SS, Sarr MG, Colby TV, et al.: Long-term survival after resection for ductal adenocarcinoma of the pancreas. Is it really improving? Ann Surg. 1995; 221(1): 59-66.

PubMed Abstract | Publisher Full Text | Free Full Text

15. Sohn TA, Yeo CJ, Cameron JL, et al:: Resected adenocarcinoma of the pancreas-616 patients: results, outcomes, and prognostic indicators.
J Gastrointest Surg. 2000; 4(6): 567-79.

PubMed Abstract | Publisher Full Text

16. Neoptolemos JP, Stocken DD, Dunn JA, et al.: Influence of resection margins on survival for patients with pancreatic cancer treated by adjuvant chemoradiation and/or chemotherapy in the ESPAC-1 randomized controlled trial. Ann Surg. 2001; 234(6): 758-68. PubMed Abstract | Publisher Full Text | Free Full Text

17. Nishimura $Y$, Hosotani R, Shibamoto $Y$, et al.: External and intraoperative radiotherapy for resectable and unresectable pancreatic cancer: analysis of survival rates and complications. Int J Radiat Oncol Biol Phys. 1997; 39(1): of surviva.

PubMed Abstract | Publisher Full Text

18. Millikan KW, Deziel DJ, Silverstein JC, et al:: Prognostic factors associated with resectable adenocarcinoma of the head of the pancreas. Am Surg. 1999; 65(7): 618-23; discussion 623-4.

PubMed Abstract

19. Benassai G, Mastrorilli M, Quarto G, et al.: Survival after pancreaticoduodenectomy for ductal adenocarcinoma of the head of the pancreas. Chir Ital. 2000; 52(3): 263-70.

PubMed Abstract

20. Kuhlmann KF, de Castro SM, Wesseling JG, et al.: Surgical treatment of pancreatic adenocarcinoma; actual survival and prognostic factors in 343 patients. Eur J Cancer. 2004; 40(4): 549-58.

PubMed Abstract | Publisher Full Text

21. Gall FP, Kessler $\mathrm{H}$, Hermanek P: Surgical treatment of ductal pancreatic carcinoma. Eur J Surg Oncol. 1991; 17(2): 173-81. PubMed Abstract

22. Trede M, Schwall G, Saeger HD: Survival after pancreatoduodenectomy. 118 consecutive resections without an operative mortality. Ann Surg. 1990; 211(4) 447-58.

PubMed Abstract | Free Full Text

23. Richter A, Niedergethmann M, Sturm JW, et al:: Long-term results of partial pancreaticoduodenectomy for ductal adenocarcinoma of the pancreatic head: 25-year experience. World J Surg. 2003; 27(3): 324-9. PubMed Abstract | Publisher Full Text

24. Takai S, Satoi S, Toyokawa $\mathrm{H}$, et al.: Clinicopathologic evaluation after resection for ductal adenocarcinoma of the pancreas: A retrospective, single-institution experience. Pancreas. 2003; 26(3): 243-9.

PubMed Abstract | Publisher Full Text

25. Li D, Xie K, Wolff R, et al.: Pancreatic cancer. Lancet. 2004; 363: 1049-57. PubMed Abstract | Publisher Full Text

26. Sauer R, Liersch T, Merkel S, et al:: Preoperative versus postoperative chemoradiotherapy for locally advanced rectal cancer: results of the German CAO/ARO/AIO-94 randomized phase III trial after a median follow-up of 11 years. J Clin Oncol. 2012; 30(16): 1926-33. PubMed Abstract | Publisher Full Text

27. $\mathrm{F}$ van Hagen $\mathrm{P}$, Hulshof MC, Van Lanschot JJ, et al:: Preoperative chemoradiotherapy for esophageal or junctional cancer. N Engl J Med. 2012; 366(22): 2074-84.

PubMed Abstract | Publisher Full Text | F1000 Recommendation

28. Raut CP, Tseng JF, Sun CC, et al.: Impact of resection status on pattern of failure and survival after pancreaticoduodenectomy for pancreatic adenocarcinoma. Ann Surg. 2007; 246(1): 52-60.

PubMed Abstract | Publisher Full Text | Free Full Text 
29. Ishikawa O, Ohhigashi H, Teshima T, et al.: Clinical and histopathological appraisal of preoperative irradiation for adenocarcinoma of the pancreatoduodenal region. J Surg Oncol. 1989; 40(3): 143-51. PubMed Abstract | Publisher Full Text

30. Lowy AM, Lee JE, Pisters PW, et al.: Prospective, randomized trial of octreotide to prevent pancreatic fistula after pancreaticoduodenectomy for malignant disease. Ann Surg. 1997; 226(5): 632-41.

PubMed Abstract | Publisher Full Text | Free Full Text

31. Cheng TY, Sheth K, White RR, et al.: Effect of neoadjuvant chemoradiation on operative mortality and morbidity for pancreaticoduodenectomy. Ann Surg Oncol. 2006; 13(1): 66-74

PubMed Abstract | Publisher Full Text

32. F Russo S, Saif MW: Neoadjuvant therapy for pancreatic cancer: an ongoing debate. Therap Adv Gastroenterol. 2016; 9(4): 429-36.

PubMed Abstract | Publisher Full Text | Free Full Text | F1000 Recommendation

33. Gillen S, Schuster T, Meyer Zum Büschenfelde C, et al:: Preoperative/neoadjuvant therapy in pancreatic cancer: a systematic review and meta-analysis of response and resection percentages. PLoS Med. 2010; 7(4): e1000267. PubMed Abstract | Publisher Full Text | Free Full Text

34. F Golcher H, Brunner TB, Witzigmann H, et al: Neoadjuvant chemoradiation therapy with gemcitabine/cisplatin and surgery versus immediate surgery in resectable pancreatic cancer: results of the first prospective randomized phase II trial. Strahlenther Onkol. 2015; 191(1): 7-16.

PubMed Abstract | Publisher Full Text | Free Full Text | F1000 Recommendation

35. van Tienhoven G, Versteijne E, Suker M, et al:: Preoperative chemoradiotherapy versus immediate surgery for resectable and borderline resectable pancreatic cancer (PREOPANC-1): A randomized, controlled, multicenter phase III trial. $J$ Clin Oncol. 2018; 36(18 suppl): LBA4002. Publisher Full Text

36. Katz MHG, Ou FS, Herman JM, et al:: Alliance for clinical trials in oncology (ALLIANCE) trial A021501: preoperative extended chemotherapy vs. chemotherapy plus hypofractionated radiation therapy for borderline resectable adenocarcinoma of the head of the pancreas. BMC Cancer. 2017; 17(1): 505. PubMed Abstract | Publisher Full Text | Free Full Text

37. $\mathrm{F}$ Hammel P, Huguet $\mathrm{F}$, van Laethem JL, et al:: Effect of Chemoradiotherapy vs Chemotherapy on Survival in Patients With Locally Advanced Pancreatic Cancer Controlled After 4 Months of Gemcitabine With or Without Erlotinib: The LAP07 Randomized Clinical Trial. JAMA. 2016; 315(17): 1844-53. PubMed Abstract | Publisher Full Text | F1000 Recommendation

38. Chauffert B, Mornex F, Bonnetain F, et al.: Phase III trial comparing intensive induction chemoradiotherapy ( $60 \mathrm{~Gy}$, infusional 5-FU and intermittent cisplatin) followed by maintenance gemcitabine with gemcitabine alone for locally advanced unresectable pancreatic cancer. Definitive results of the 2000-01 FFCD/SFRO study. Ann Oncol. 2008; 19(9): 1592-9. PubMed Abstract | Publisher Full Text

39. F Chung SY, Chang JS, Lee BM, et al:: Dose escalation in locally advanced pancreatic cancer patients receiving chemoradiotherapy. Radiother Oncol. 2017; 123(3): 438-45.

PubMed Abstract | Publisher Full Text | F1000 Recommendation

40. Krishnan S, Chadha AS, Suh Y, et al: Focal Radiation Therapy Dose Escalation Improves Overall Survival in Locally Advanced Pancreatic Cancer Patients Receiving Induction Chemotherapy and Consolidative Chemoradiation. Int $J$ Radiat Oncol Biol Phys. 2016; 94(4): 755-65. PubMed Abstract | Publisher Full Text | Free Full Text

41. F Herman JM, Chang DT, Goodman KA, et al:: Phase 2 multi-institutional trial evaluating gemcitabine and stereotactic body radiotherapy for patients with locally advanced unresectable pancreatic adenocarcinoma. Cancer. 2015; 121(7): 1128-37.

PubMed Abstract | Publisher Full Text | Free Full Text | F1000 Recommendation

42. Katz MH, Pisters PW, Evans DB, et al.: Borderline resectable pancreatic cancer: the importance of this emerging stage of disease. J Am Coll Surg. 2008; 206(5): 833-46; discussion 846-8.

PubMed Abstract | Publisher Full Text | Free Full Text

43. F Ferrone CR, Marchegiani G, Hong TS, et al.: Radiological and surgical implications of neoadjuvant treatment with FOLFIRINOX for locally advanced and borderline resectable pancreatic cancer. Ann Surg. 2015; 261(1): 12-7. PubMed Abstract | Publisher Full Text | Free Full Text | F1000 Recommendation

44. Venkatesulu BP, Mallick S, Lin SH, et al:: A systematic review of the influence of radiation-induced lymphopenia on survival outcomes in solid tumors. Crit Rev Oncol Hematol. 2018; 123: 42-51.

PubMed Abstract | Publisher Full Text

45. Balmanoukian A, Ye X, Herman J, et al.: The association between treatmentrelated lymphopenia and survival in newly diagnosed patients with resected adenocarcinoma of the pancreas. Cancer Invest. 2012; 30(8): 571-6. PubMed Abstract | Publisher Full Text | Free Full Text

46. Wild AT, Ye X, Ellsworth SG, et al:: The Association Between Chemoradiationrelated Lymphopenia and Clinical Outcomes in Patients With Locally Advanced Pancreatic Adenocarcinoma. Am J Clin Oncol. 2015; 38(3): 259-65. PubMed Abstract | Publisher Full Text | Free Full Text

47. Chadha AS, Liu G, Chen HC, et al:: Does Unintentional Splenic Radiation Predict Outcomes After Pancreatic Cancer Radiation Therapy? Int J Radiat
Oncol Biol Phys. 2017; 97(2): 323-32

PubMed Abstract | Publisher Full Text

48. Dahlin AM, Henriksson ML, Van Guelpen B, et al: Colorectal cancer prognosis depends on T-cell infiltration and molecular characteristics of the tumor. Mod Pathol. 2011; 24(5): 671-82.

PubMed Abstract | Publisher Full Text

49. Yasuda K, Nirei T, Sunami E, et al.: Density of CD4(+) and CD8(+) T lymphocytes in biopsy samples can be a predictor of pathological response to chemoradiotherapy (CRT) for rectal cancer. Radiat Oncol. 2011; 6: 49. PubMed Abstract | Publisher Full Text | Free Full Text

50. Teixidó C, González-Cao M, Karachaliou N, et al:: Predictive factors for immunotherapy in melanoma. Ann Transl Med. 2015; 3(15): 208. PubMed Abstract | Publisher Full Text | Free Full Text

51. Seung SK, Curti BD, Crittenden M, et al:: Phase 1 study of stereotactic body radiotherapy and interleukin-2--tumor and immunological responses. Sci Transl Med. 2012; 4(137): 137ra74

PubMed Abstract | Publisher Full Text

52. Wild AT, Herman JM, Dholakia AS, et al.: Lymphocyte-Sparing Effect of Stereotactic Body Radiation Therapy in Patients With Unresectable Pancreatic Cancer. Int J Radiat Oncol Biol Phys. 2016; 94(3): 571-9.

PubMed Abstract | Publisher Full Text | Free Full Text

53. Faltynek CR, Wang S, Miller D, et al:: Administration of human recombinant IL-7 to normal and irradiated mice increases the numbers of lymphocytes and some immature cells of the myeloid lineage. J Immunol. 1992; 149(4): 1276-82. PubMed Abstract

54. F Mathios D, Park CK, Marcus WD, et al:: Therapeutic administration of IL15 superagonist complex ALT-803 leads to long-term survival and durable antitumor immune response in a murine glioblastoma model. Int $J$ Cancer. 2016; 138(1): 187-94.

PubMed Abstract | Publisher Full Text | Free Full Text | F1000 Recommendation

55. F Pilones K, Aryankalayil J, Formenti S, et al:: Intratumoral IL-15 potentiates radiation-induced anti-tumor immunity. J Immunother Cancer. 2015; 3(Suppl 2): P239. Publisher Full Text | Free Full Text | F1000 Recommendation

56. Clinicaltrials.gov: A Phase I and Pilot Study of the Effect of rhlL-7-hyFc (NT-17) on CD4 Counts in Patients With High Grade Gliomas and Severe Treatmentrelated CD4 Lymphopenia After Concurrent Radiation and Temozolomide. ClinicalTrials.gov. [online]. 2018.

Reference Source

57. Recombinant Interleukin-15 in Treating Patients With Advanced Melanoma KC, Non-small Cell Lung Cancer, or Squamous Cell Head and Neck Cancer. ClinicalTrials.gov [online]. [Accessed April 5 2017].

Reference Source

58. F Dudley ME, Yang JC, Sherry R, et al.: Adoptive cell therapy for patients with metastatic melanoma: evaluation of intensive myeloablative chemoradiation preparative regimens. J Clin Oncol. 2008; 26(32): 5233-9. PubMed Abstract | Publisher Full Text | Free Full Text | F1000 Recommendation

59. Campian JL, Ye X, Gladstone DE, et al:: Pre-radiation lymphocyte harvesting and post-radiation reinfusion in patients with newly diagnosed high grade gliomas. J Neurooncol. 2015; 124(2): 307-16.

PubMed Abstract | Publisher Full Text | Free Full Text

60. Thind K, Padrnos LJ, Ramanathan RK, et al:: Immunotherapy in pancreatic cancer treatment: a new frontier. Therap Adv Gastroenterol. 2017; 10(1): 168-94. PubMed Abstract | Publisher Full Text | Free Full Text

61. Reynders K, De Ruysscher D: Radiotherapy and Immunotherapy: Improving Cancer Treatment through Synergy. Prog Tumor Res. 2015; 42: 67-78. PubMed Abstract | Publisher Full Text

62. Vatner RE, Cooper BT, Vanpouille-Box C, et al:: Combinations of immunotherapy and radiation in cancer therapy. Front Oncol. 2014; 4: 325 PubMed Abstract | Publisher Full Text | Free Full Text

63. Vanpouille-Box C, Diamond JM, Pilones KA, et al:: TGF $\beta$ Is a Master Regulator of Radiation Therapy-Induced Antitumor Immunity. Cancer Res. 2015; 75(11): 2232-42.

PubMed Abstract | Publisher Full Text | Free Full Text

64. Kuo P, Bratman SV, Shultz DB, et al:: Galectin-1 mediates radiation-related lymphopenia and attenuates NSCLC radiation response. Clin Cancer Res. 2014; 20(21): 5558-69.

PubMed Abstract | Publisher Full Text | Free Full Text

65. Bernstein MB, Krishnan S, Hodge JW, et al:: Immunotherapy and stereotactic ablative radiotherapy (ISABR): a curative approach? Nat Rev Clin Oncol. 2016; 13(8): 516-24

PubMed Abstract | Publisher Full Text | Free Full Text

66. Immunotherapy and SBRT Study in Borderline Resectable Pancreatic Cancer. ClinicalTrials.gov.

Reference Source

67. Pancreatic Tumor Cell Vaccine (GVAX), Low Dose Cyclophosphamide, Fractionated Stereotactic Body Radiation Therapy (SBRT), and FOLFIRINOX Chemotherapy in Patients With Resected Adenocarcinoma of the Pancreas. ClinicalTrials.gov.

Reference Source

68. Losartan and Nivolumab in Combination With FOLFIRINOX and SBRT in 
Localized Pancreatic Cancer. ClinicalTrials.gov.

Reference Source

69. Nivolumab and Ipilimumab and Radiation Therapy in MSS and MSI High Colorectal and Pancreatic Cancer. ClinicalTrials.gov.

Reference Source

70. Safety and Immunological Effect of Pembrolizumab in Resectable or Borderline Resectable Pancreatic Cancer. ClinicalTrials.gov.

Reference Source

71. Study With CY, Pembrolizumab, GVAX, and SBRT in Patients With Locally
Advanced Pancreatic Cancer. ClinicalTrials.gov.

Reference Source

72. Aliru ML, Schoenhals JE, Venkatesulu BP, et al.: Radiation therapy and immunotherapy: what is the optimal timing or sequencing? Immunotherapy. 2018; 10(4): 299-316.

PubMed Abstract | Publisher Full Text | Free Full Text

73. Whatcott $\mathrm{CJ}$, Diep $\mathrm{CH}$, Jiang $\mathrm{P}$, et al.: Desmoplasia in Primary Tumors and Metastatic Lesions of Pancreatic Cancer. Clin Cancer Res. 2015; 21(15): 3561-8. PubMed Abstract | Publisher Full Text | Free Full Text 


\section{Open Peer Review}

\section{Current Peer Review Status:}

\section{Editorial Note on the Review Process}

Faculty Reviews are review articles written by the prestigious Members of Faculty Opinions. The articles are commissioned and peer reviewed before publication to ensure that the final, published version is comprehensive and accessible. The reviewers who approved the final version are listed with their names and affiliations.

\section{The reviewers who approved this article are:}

\section{Version 1}

\section{Jeffrey Meyer}

Department of Radiation Oncology and Molecular Radiation Sciences, Johns Hopkins School of Medicine, Baltimore, USA

Competing Interests: No competing interests were disclosed.

\section{Terence Sio}

Department of Radiation Oncology, Mayo Clinic, Phoenix, Arizona, USA

Competing Interests: No competing interests were disclosed.

The benefits of publishing with F1000Research:

- Your article is published within days, with no editorial bias

- You can publish traditional articles, null/negative results, case reports, data notes and more

- The peer review process is transparent and collaborative

- Your article is indexed in PubMed after passing peer review

- Dedicated customer support at every stage

For pre-submission enquiries, contact research@f1000.com 